\title{
Mapping of Soil Quality Index (SQI) for Paddy Fields Using Sentinel-2 Imagery, Laboratory Analysis, and Principal Component Analysis
}

\author{
Putri Tunjung Sari ${ }^{1, *}$, Indarto Indarto ${ }^{1}$, Marga Mandala ${ }^{1}$, Bowo Eko Cahyono ${ }^{2}$ \\ ${ }^{1}$ Department of Natural Resources and Environmental Management, University of Jember, Jl. \\ Kalimantan No. 37 Jember, 68121, Indonesia \\ ${ }^{2}$ Faculty of Mathematics and Natural Sciences, University of Jember, Jl. Kalimantan No. 37 \\ Jember, 68121, Indonesia
}

Received 2 June 2021/Revised 15 July 2021/Accepted 26 July 2021/Published 17 August 2021

\begin{abstract}
The use of intensive chemical inputs causes lower availability of nutrients, organic matter, cation exchange capacity, and soil degradation.Therefore, this study aims to assess the soil quality index (SQI) for paddy fields in Jember, East Java, Indonesia. Input data for this study consist of land cover (interpreted from the Sentinel-2 image), soil type, and slope maps. Furthermore, the procedure to calculate soil quality index (SQI) include (1) spatial analysis to create the land unit, (2) preparation of soil sampling, (3) soil chemical analysis, (4) principal component analysis (PCA), and (5) reclassifying soil quality index (SQI). The PCA results showed that three variables i.e., \% sand, total- P, and \% silt were strongly correlated to SQI, while three classes namely very low, low, and medium of SQI were sufficiently used to describe the spatial variability of the paddy field. Furthermore, approximately $41.14 \%$ of the paddy field area were classed as very low while $52.23 \%$, and $6.63 \%$ were categorized as low and medium SQI respectively. Based on the results, about $93.37 \%$ of paddy fields in Jember Regency still require improvement in soil quality via the addition of ameliorants such as organic fertilizers to increase quality and productivity. This application needs to focus on areas with very low-low quality hence, the quality increased to the medium category.
\end{abstract}

Keywords: Mapping; Soil Quality Index (SQI); PCA; Paddy field

\section{Introduction}

The Increasing population and food demand have forced farmers to intensify and extend agricultural land to improve productivity (Ren et al., 2020). Agricultural intensification is an activity that aims to optimize agrarian land by providing additional inputs to increase productivity (Xie et al., 2019). Meanwhile, extensification involves expanding agricultural land and minimizing external inputs (Van Grinsven et al., 2015). The use of intensive chemical inputs such as fertilizers and pesticides indicates agricultural intensification activities. However, most farmers do not understand the concept of sustainable agriculture (Johannes et al., 2019;Terano et al., 2015).

*Corresponding author.

Email address: putritunjung36@gmail.com (Putri Tunjung Sari) 
The continuous use of chemical fertilizers and pesticides has negative impacts on the soil (Li et al., 2018). A previous study stated that fertilizer and pesticide residues settle in the soil thereby increasing its acidity (Asvini \& Jithesh, 2018). Other impacts observed include lower availability of nutrients, organic matter, and cation exchange capacity (Hung et al., 2019; Maas et al., 2017). Agricultural extensification is usually conducted by land conversion and forest clearing. Mohawesh et al. (2015) stated that changes in land-use affect soil quality, while Pierzynski et al. (2005) defined soil quality as multicriteria analysis results of chemical, physical and biological properties. Furthermore, the characteristics of good soil usually comprise (1) good drainage, (2) good water holding capacity (WHC), (3) less erosion, and (4) high nutrient content (Seifu \& Elias, 2018). Good quality soil supports optimal plant productivity. Meanwhile, soil quality assessments are used to identify, evaluate and determine the appropriate technology for land management and sustainability (Roy et al., 2015).

Rice is widely known as the principal food of the Indonesians, therefore, the presence of paddy fields is essential to support agricultural land and fulfill food demand. Generally, farmers overuse fertilizers and pesticides, which in turn decrease the land quality. Moreover, the input cost of chemical fertilizers and pesticides is expensive compared to the benefit in the form of increase in production (Xie et al., 2019). This condition has also been exacerbated by the increased price of chemical fertilizers in the market, hence, farmers spend much money for less productive results. The benefits of calculating SQI include (1) increase farmers' awareness of land mismanagement, (2) mapping complex land variability, and (3) as a guide for sustainable management plan (Ren et al., 2020; Lin \& Fukushima, 2016).

Previous studies only referred to one of the soil's chemical, physical or biological properties to determine SQI (Supriyadi et al., 2019; Supriyadi et al., 2018). However, this study combines the three parameters to categorize the soil quality (Bahnemiri et al., 2019). Soil quality analysis based on remote sensing is needed to assess land variability (Reddy et al., 2020). Meanwhile, remote sensing technology is commonly used to classify land, based on several criteria with high accuracy (Hore et al., 2020).

The combination of remote sensing and principal component analysis (PCA) is effective in assessing soil quality. The PCA method is used for data reduction and selection of the primary indicator that best represents the analysis and the results are presented in the form of a minimum data set (MDS). Furthermore, the MDS component reduces the burden of indicators in the SQI calculation model and prevents data redundancies (Mukherjee \& Lal, 2014). 
SQI was more interpolated using the Inverse Distance Weighting (IDW) method which predicts value base on the distance between the data point and the expected location. The expected value is calculated as the number of measured data points located in a specific search environment on the predicted site (Bofana \& Costa, 2017). Abdel Rahman et al. (2021) stated that the IDW technique is the most commonly used method to predict soil properties. Only a few studies focused on assessing soil quality based on one soil characteristic. Also, there are limited studies on the physical, chemical, or biological properties only. Therefore, this study aims to assess soil quality based on the physical, chemical, and biological properties by combining spatial analysis.

\section{Methods}

This study was conducted from December 2020 to April 2021, and the study area covers all paddy fields in Jember Regency, East Java, Indonesia (Figure. 1).

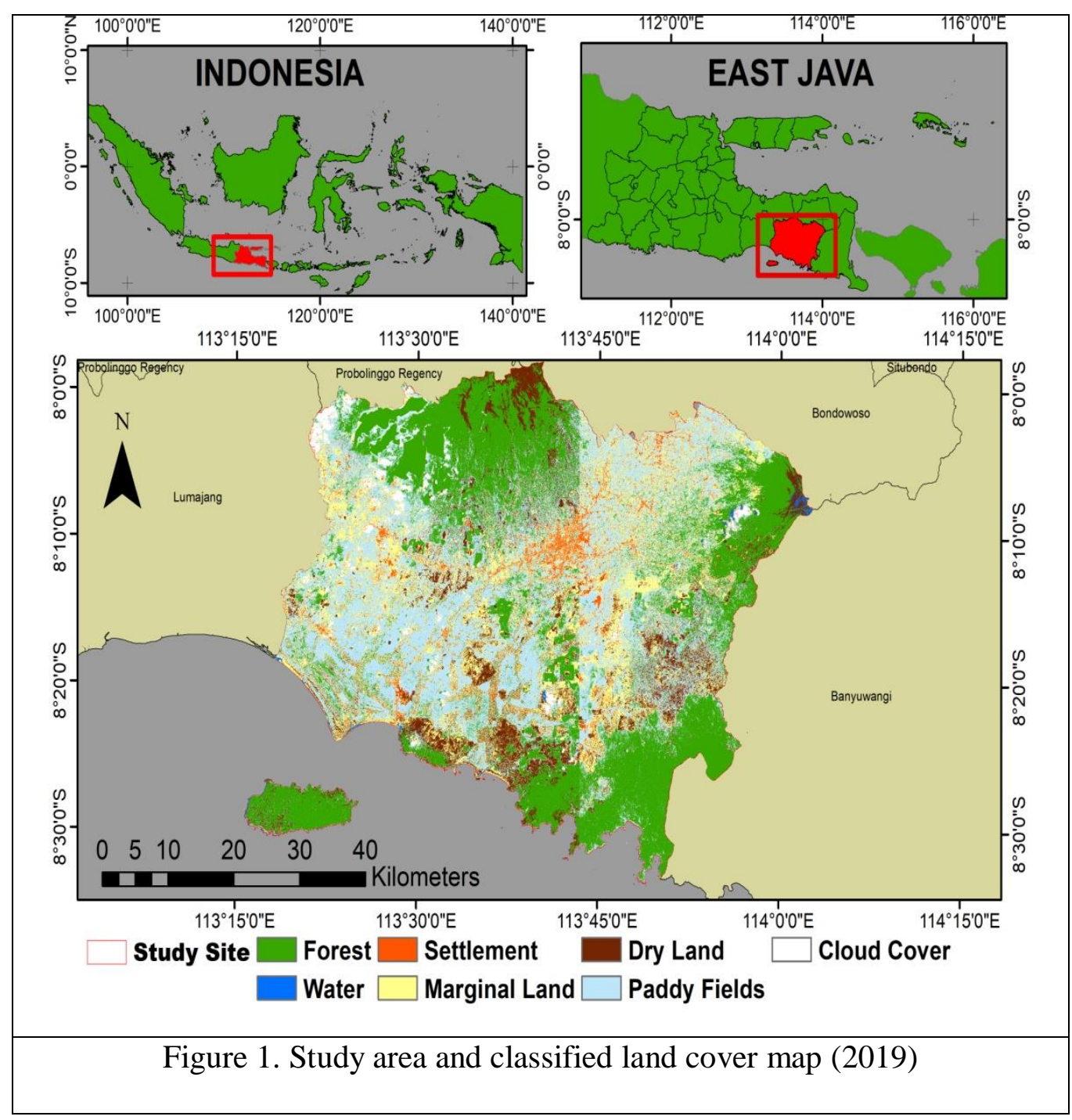


2.1 Input Data and Tool Used

The three maps (Table 1) were used as input data for this study.

Table 1. Research materials

\begin{tabular}{cc}
\hline Material & Sources \\
\hline Land cover map & Sentinel 2A satellite image data processing \\
Soil type map & (USGS, 2019) \\
Slope map & (Balai Penelitian Tanah, 2015) \\
& Derived from DEMNAS (BIG, 2019) \\
\hline
\end{tabular}

The tools used in this study consist of soil sampling and laboratory analysis equipment, as well as software for processing. Soil sampling equipment consists of a soil drill, shovel, tape measure, and plastic clips, while the laboratory equipment includes atomic absorption spectrophotometer (AAS), $\mathrm{pH}$ meter, and oven (Table 2). The data obtain were analyzed using Multispect, GIS software, and statistical tools.

Table 2. List of tools used

\begin{tabular}{cc}
\hline Tool & Specification and function \\
\hline Soil drill & To take soil samples \\
Shovel & To take soil samples \\
AAS & Soil potassium analysis \\
Musltispec & Land cover analysis \\
Q-GIS & Soil Quality Index (SQI) calculations \\
\hline
\end{tabular}

Source: (Supriyadi et al., 2018)

\subsection{Research Procedure}

The research procedure consists of (1) determination of land unit, (2) soil sampling, (3) laboratory analysis, (4) principal component analysis (PCA), (5) scoring and classification, and (6) assessment of soil quality index (SQI).

\subsubsection{Land unit and soil sampling}

The number of the land unit was determined by overlaying and intersecting three input maps, i.e., land cover, soil type, and slope maps, as illustrated in Figure 2. First, the land cover map was classified into two namely paddy fields and non-paddy fields, then, the paddy field was converted from raster to polygon vector layer. Furthermore, the soil type and slope map were clipped with polygon paddy field maps. The two maps results are united to create a land unit map. 
Putri Tunjung Sari et al. / Geosfera Indonesia 6 (2), 2021, 173-188

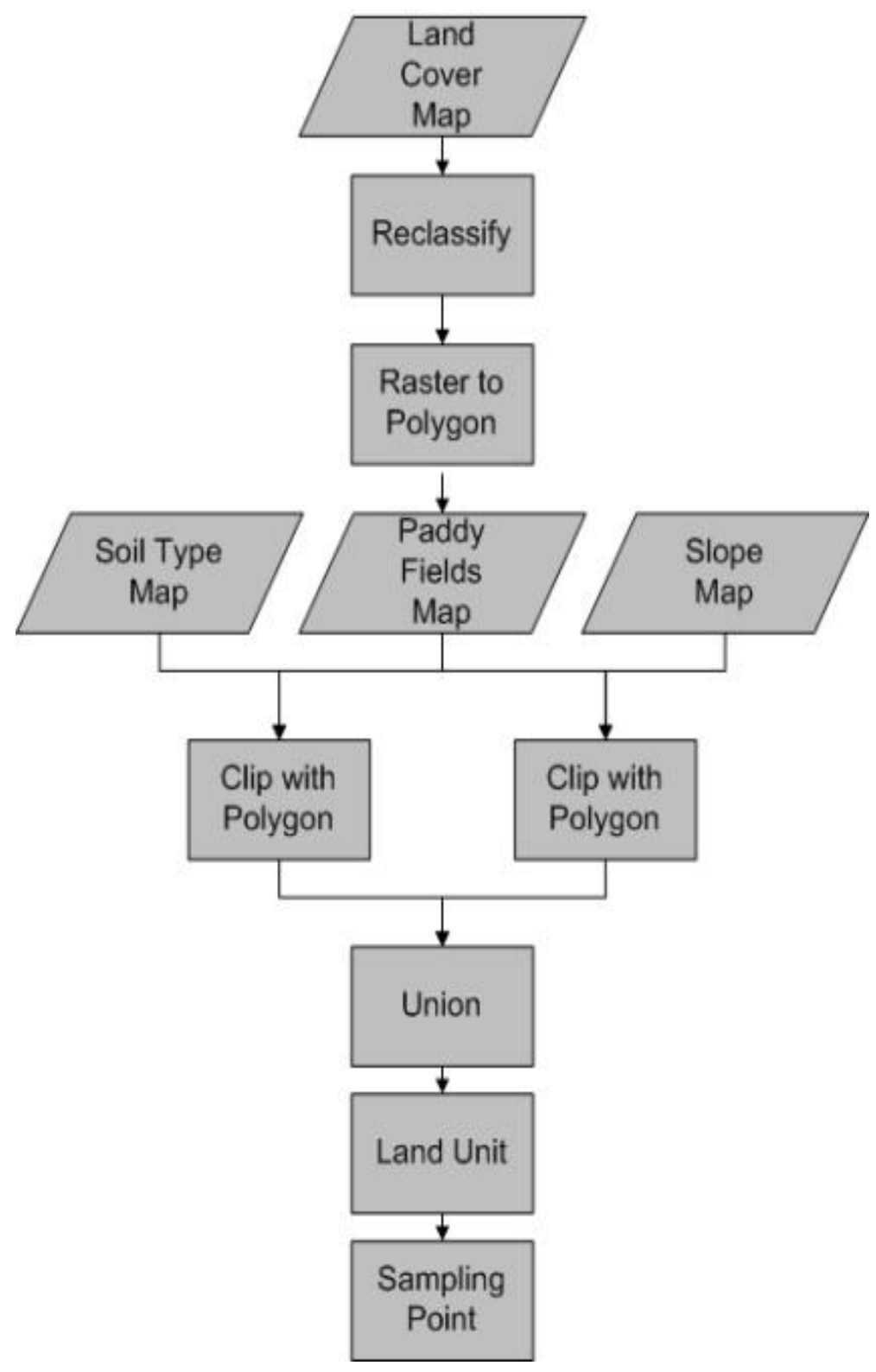

Figure 2. Procedure to determine the land unit and soil sampling

The soil samples were collected from each land unit map, while four samples for each land unit were then compiled using the soil drill method. Furthermore, each land unit was divided into four regions, and sampling was carried out in each area. Table 3 shows the 24 samples locations, the samples for each class were then mixed and compiled. Figure 3 shows the different soil color photographs taken from (9) nine locations. 
Putri Tunjung Sari et al. / Geosfera Indonesia 6 (2), 2021, 173-188

Table 3. Description of sampling point

\begin{tabular}{|c|c|c|c|}
\hline No Point & Location & Soil Type (USDA) & Slope \\
\hline 1 & $8^{\circ} 9^{\prime} 35.03^{\prime \prime S}$ and11352'15.78"E & Entisols & $>15 \%$ \\
\hline 2 & $8^{\circ} 28^{\prime} 32.64 " \mathrm{~S}$ and $113^{\circ} 44^{\prime} 11.57^{\prime \prime E}$ & Entisols & $>15 \%$ \\
\hline 3 & $8^{\circ} 25^{\prime} 33.69^{\prime \prime S}$ and $113^{\circ} 33^{\prime} 22.83^{\prime \prime E}$ & Entisols & $>15 \%$ \\
\hline 4 & $8^{\circ} 12^{\prime} 36.80^{\prime \prime S}$ and $113^{\circ} 49^{\prime} 35.96^{\prime E}$ & Entisols & $>15 \%$ \\
\hline 5 & $8^{\circ} 4^{\prime} 5.05^{\prime \prime S}$ and $113^{\circ} 41^{\prime} 34.13^{\prime \prime E}$ & Inceptisols & $>15 \%$ \\
\hline 6 & $8^{\circ} 3^{\prime} 32.04^{\prime \prime} \mathrm{S}$ and $113^{\circ} 41^{\prime} 14.87^{\prime \prime E}$ & Andisols & $>15 \%$ \\
\hline 7 & $8^{\circ} 15^{\prime} 46.99^{\prime \prime} \mathrm{S}$ and $113^{\circ} 26^{\prime} 39.22^{\prime \prime E}$ & Entisols & $>15 \%$ \\
\hline 8 & $8^{\circ} 5^{\prime} 7.33^{\prime \prime S}$ and $113^{\circ} 55^{\prime} 41.86 " \mathrm{E}$ & Entisols & $>15 \%$ \\
\hline 9 & $8^{\circ} 7^{\prime} 24.08^{\prime \prime} \mathrm{S}$ and $113^{\circ} 32^{\prime} 10.28^{\prime \prime E}$ & Inceptisols & $>15 \%$ \\
\hline 10 & $8^{\circ} 22^{\prime} 33.311^{\prime \prime S}$ and $113^{\circ} 29^{\prime} 9.56 " \mathrm{E}$ & Entisols & $>15 \%$ \\
\hline 11 & $8^{\circ} 3^{\prime} 47.32^{\prime \prime} \mathrm{S}$ and $113^{\circ} 54^{\prime} 46.28^{\prime \prime E}$ & Entisols & $0-15 \%$ \\
\hline 12 & $8^{\circ} 9^{\prime} 52.26^{\prime \prime S}$ and $113^{\circ} 49^{\prime} 8.08^{\prime \prime E}$ & Entisols & $0-15 \%$ \\
\hline 13 & $8^{\circ} 25^{\prime} 20.38^{\prime \prime S}$ and $113^{\circ} 38^{\prime} 26.77^{\prime E}$ & Alfisols & $0-15 \%$ \\
\hline 14 & $8^{\circ} 21^{\prime} 8.97 " \mathrm{~S}$ and $113^{\circ} 43^{\prime} 32.911^{\prime E}$ & Entisols & $0-15 \%$ \\
\hline 15 & $8^{\circ} 23^{\prime} 18.30^{\prime \prime S}$ and $113^{\circ} 29^{\prime} 55.03^{\prime \prime E}$ & Alfisols & $0-15 \%$ \\
\hline 16 & $8^{\circ} 22^{\prime} 29.711^{\prime S} \mathrm{~S}$ and $113^{\circ} 27^{\prime} 25.17^{\prime \prime E}$ & Entisols & $0-15 \%$ \\
\hline 17 & $8^{\circ} 11^{\prime} 42.78^{\prime \prime S}$ and $113^{\circ} 48^{\prime} 39.85^{\prime \prime E}$ & Entisols & $0-15 \%$ \\
\hline 18 & $8^{\circ} 8^{\prime} 8.48^{\prime \prime S}$ and $113^{\circ} 43^{\prime} 37.86 " \mathrm{E}$ & Inceptisols & $0-15 \%$ \\
\hline 19 & $8^{\circ} 19^{\prime} 13.73^{\prime \prime S}$ and $113^{\circ} 39^{\prime} 55.27^{\prime \prime E}$ & Alfisols & $0-15 \%$ \\
\hline 20 & $8^{\circ} 13^{\prime} 53.39^{\prime \prime} \mathrm{S}$ and $113^{\circ} 36^{\prime} 39.03^{\prime \prime E}$ & Entisols & $0-15 \%$ \\
\hline 21 & $8^{\circ} 24^{\prime} 10.97^{\prime \prime S}$ and $113^{\circ} 35^{\prime} 25.46^{\prime \prime E}$ & Entisols & $0-15 \%$ \\
\hline 22 & $8^{\circ} 5^{\prime} 51.76 " \mathrm{~S}$ and $113^{\circ} 55^{\prime} 0.90 " \mathrm{E}$ & Entisols & $0-15 \%$ \\
\hline 23 & $8^{\circ} 10^{\prime} 43.78^{\prime \prime S}$ and $113^{\circ} 34^{\prime} 45.28^{\prime \prime E}$ & Inceptisols & $0-15 \%$ \\
\hline 24 & $8^{\circ} 17^{\prime} 0.95^{\prime \prime S}$ and $113^{\circ} 21^{\prime} 10.73^{\prime \prime E}$ & Entisols & $0-15 \%$ \\
\hline
\end{tabular}

Interpreted from: (USDA - Soil Survey Staff, 2014).

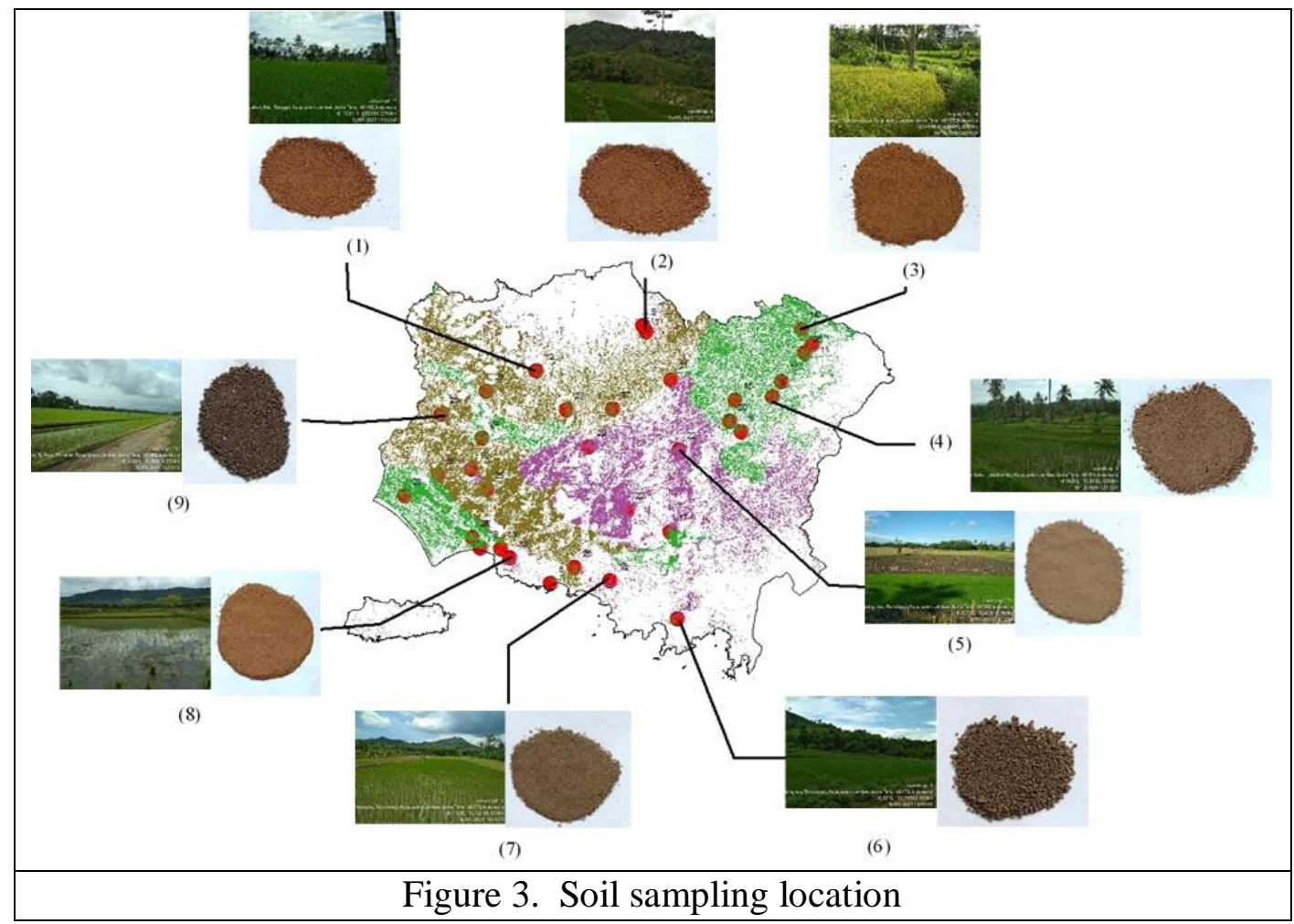




\subsubsection{Laboratory Analysis}

Laboratory analysis was used to measure the physical, chemical, and biological properties of the soil samples. The soil samples were initially dried and sieved. The physical properties were analyzed using a $2 \mathrm{~mm}$ sieve, while the chemical analysis used a $0.5 \mathrm{~mm}$ sieve. Table 4 shows the physical, chemical, and biological properties of soil samples used in this study.

Table 4. Physical, chemical, and biological properties

\begin{tabular}{|c|c|c|}
\hline Variable & Sample type & Method \\
\hline \multicolumn{3}{|c|}{ Chemical properties } \\
\hline $\mathrm{pH}$ & Disturbed Soil & The soil-water suspension $(1: 25)$ \\
\hline Total Phosphorus & Disturbed Soil & Percolation with $\mathrm{HCl} 25 \%$ \\
\hline Available Potassium (K) & Disturbed Soil & Neutral $\mathrm{N} \mathrm{NH}_{4} \mathrm{OAc}$ \\
\hline \multicolumn{3}{|c|}{ Physical properties } \\
\hline$\%$ Sand & Disturbed Soil & Pippet \\
\hline$\%$ Silt & Disturbed Soil & Pippet \\
\hline$\%$ Clay & Disturbed Soil & Pippet \\
\hline Effective soil depth & Disturbed Soil & Measurement \\
\hline \multicolumn{3}{|c|}{ Biological properties } \\
\hline C-organic & Disturbed Soil & Curmis \\
\hline
\end{tabular}

Sources: (Japan International Cooperation Agency (JICA), 2014; Panday et al., 2019)

\subsubsection{Principal Component Analysis (PCA)}

The soil properties determined via laboratory analysis were then used as input for correlation and principal component analysis (PCA). The data processed by PCA include $\mathrm{pH}$, total phosphorus (P), available potassium (K), \% sand, \% silt, \% clay, effective soil depth, and c-organic. Meanwhile, the procedure for this method includes (1) analyzing the correlation between factors, (2) conducting principal component analysis (PCA), and (3) determining the minimum data set.

\subsubsection{Assessment of Soil Quality Index (SQI)}

SQI was calculated and performed using GIS software. First, the MDS variable component was added to the sampling points,then, the indicator was interpolated using Inverse Distance Weighted (IDW). The results were then used to calculate SQI, using the formula in equation 1 (Eq.1):

$$
\mathrm{SQI}=\sum_{i=1}^{n} W i x \text { Si }
$$

where, $\mathrm{Wi}=$ weighting factor; and $\mathrm{Si}=$ the indicator score for variable $\mathrm{i}$. Then, Table 5 shows the score and class used to determine the SQI. 
Putri Tunjung Sari et al. / Geosfera Indonesia 6 (2), 2021, 173-188

Table 5. Class of Soil Quality Index

\begin{tabular}{cc}
\hline Score & Class of Soil Quality Index \\
\hline $0.80-1.00$ & Very good \\
$0.60-0.79$ & Good \\
$0.40-0.59$ & Medium \\
$0.20-0.39$ & Low \\
$0.00-0.19$ & Very low \\
\hline
\end{tabular}

Sources: (Nusantara et al., 2018)

\section{Results and Discussion}

\subsection{Land Unit Map}

The number of land units were determined by overlaying and intersecting three input maps, i.e., land cover, soil type, and slope maps. The land cover map was interpreted from the Sentinel-2 image of the area of interest (AOI) downloaded from the USGS website, which was then processed, and classified. After the pre-treatment task i.e., atmospheric correction, a mosaic of 4 scenes, composite, and image enhancement, the sentinel images were then classified using the supervised method and maximum likelihood algorithm following the standard image processing procedure of Multispec TM. Furthermore, the land cover classification accuracy reached 99\%, while the thematic land cover obtained from the classification processes showed 5 primary classes, namely (1) annual vegetation which includes forested area and plantation, (2) settlement representing urban and pavement area, as well as other public facilities, (3) dryland or shrubland, (4) marginal land representing area occupied by heterogeneous agricultural land, cropland, and rural areas, (5) water body, and (6) paddy field, as shown in Figure 1.

Soil type map was extracted from layer database and obtained from the Soil research institute ( SRI, 1966). The soil type map scale was 1:250.000, and the layer was then clipped with a regency boundary. Furthermore, the slope map was derived from DEMNAS (Digital elevation model at the national level) downloaded from the official website of the National Geospatial Agency (BIG). The DEMNAS had spatial pixel resolution relatively similar to sentinel image $( \pm 10 \mathrm{~m})$. Therefore, Jember Regency has six (6) land unit classes, representing paddy fields as shown in Figure 4. 
Putri Tunjung Sari et al. / Geosfera Indonesia 6 (2), 2021, 173-188

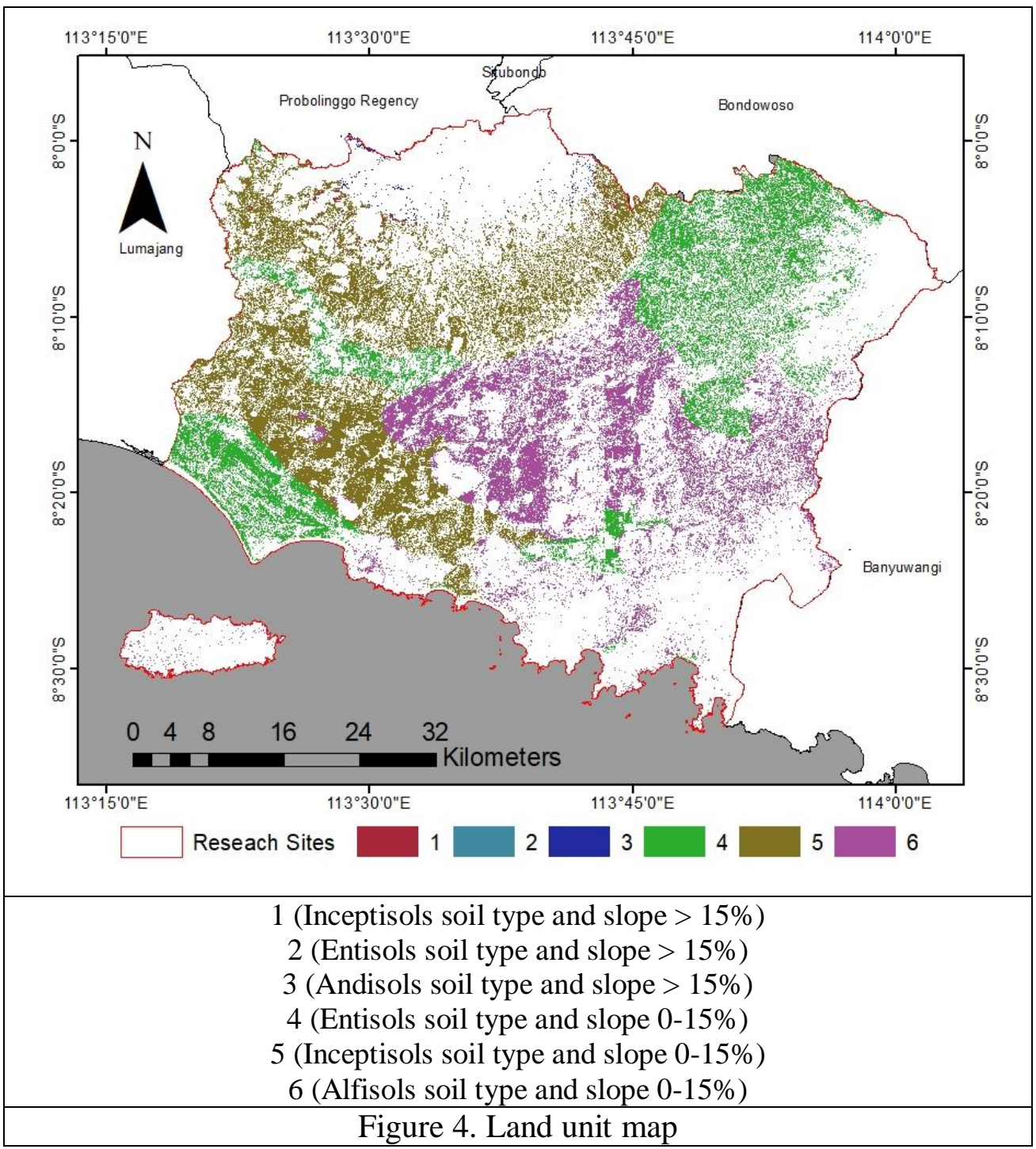

\subsection{Soil Properties of Paddy Fields}

Table 6 contains the soil properties measured using laboratory analysis. Soil properties were collect at 24 sampling points, meanwhile, the laboratory analysis results of the chemical, physical and biological properties varied. Each parameter affects the availability of plant nutrients.

Table 6. Soil properties

\begin{tabular}{|c|c|c|c|c|}
\hline Variables & Mean & SE & Min & Max \\
\hline$\overline{\mathrm{pH}}$ & 7.01 & 0.45 & 6.04 & 7.8 \\
\hline $\begin{array}{l}\text { Total P } \\
(\mathrm{mg} / 100 \mathrm{~g})\end{array}$ & 12.29 & 4.81 & 4.86 & 29.83 \\
\hline Available K (me/100 g) & 1.25 & 0.52 & 0.47 & 1.25 \\
\hline Sand $(\%)$ & 48.10 & 23.22 & 4.97 & 88.99 \\
\hline Silt (\%) & 24.39 & 22.76 & 1.85 & 89.08 \\
\hline Clay (\%) & 27.50 & 16.16 & 5.22 & 65.26 \\
\hline Soil Depth $(\mathrm{cm})$ & 36.36 & 10.25 & 25 & 70 \\
\hline C-organic (\%) & 2.42 & 0.44 & 1.28 & 3.27 \\
\hline
\end{tabular}

Note : $\mathrm{SE}=$ Standart Error 
Putri Tunjung Sari et al. / Geosfera Indonesia 6 (2), 2021, 173-188

The results show the variability in chemical, physical, and biological characteristics of soil samples with $\mathrm{pH}$ values ranging from $6.04-7.8$, and an average of 7.01. This value is classified as slightly acidic to slightly alkaline ( $\mathrm{Li}$ et al., 2018). When the soil $\mathrm{pH}$ is too alkaline, nutrients become unavailable for plants, meanwhile, the optimal soil $\mathrm{pH}$ for plants is 6.5-7 (Hanafiah, 2018).

The total P-value between 4.86 - $29.83 \mathrm{mg} / 100 \mathrm{~g}$ was categorized as the very low to intermediate class (Eviati \& Sulaeman, 2009). P nutrients are essentially needed by plants, especially in the generative phase (Yao et al., 2020). Furthermore, plants absorb P elements in the form of primary and secondary orthophosphates ions $\left(\mathrm{H}_{2} \mathrm{PO}_{4}{ }^{-}\right.$and $\left.\mathrm{HPO}_{4}{ }^{2-}\right)$. Plants absorb $\mathrm{P}$ in the form of $\mathrm{H}_{2} \mathrm{PO}_{4}^{-}$when the $\mathrm{pH}$ is low and HPO42- under high $\mathrm{pH}$ (Hanafiah, 2018). Table 6 shows a relatively neutral $\mathrm{pH}$ value, hence, plants absorb $\mathrm{P}$ in the form of $\mathrm{HPO}_{4}^{2-}$.

The potassium $(\mathrm{K})$ value ranged between $0.47-1.25 \mathrm{me} / 100 \mathrm{~g}$ and is classed as the medium to high category. This nutrient is essentially needed by plants to fill rice grains (Banerjee et al., 2018). Potassium is a mobile element, hence leaching easily occurs. Furthermore, the high amount of potassium needs to be balanced with high organic $\mathrm{C}$ which reduces the rate of erosion hence, the amount of leaching is reduced. Table 6 shows that the C-organic value ranged between $1.28-3.27 \%$ ( from low to high). This content serves as an energy source for soil microorganisms, reduces erosion, improves soil texture and structure (Arunrat et al., 2020).

Soil texture is the ratio between the fraction of sand, silt, and clay. Meanwhile, clay fraction is very critical in providing soil nutrients. Clay is a is negatively charged soil fraction that binds to cations needed by plants (Arunrat et al., 2020). The texture analysis results of the 3 fractions (sand, silt, clay) also vary (Table 6). Soil dominated by clay fraction has more nutrients compared to sand fraction. Sandy soils loss water rapidly and are unable to hold nutrients.

The rice fields in Jember Regency also have varying soil depths. Table 6 shows that the effective soil depth values ranged from $25-70 \mathrm{~cm}$. It is defined as the depth of the soil that plant roots are able to penetrate. Rice fields are managed intensively through a process of plowing, this condition causes silting of the soil adequate depth.

\subsection{Principal Component Analysis (PCA)}

The principal component analysis consists of correlation analysis and determination of the minimum data set (MDS). MDS is a variable used in determining the soil quality index 
Putri Tunjung Sari et al. / Geosfera Indonesia 6 (2), 2021, 173-188

(SQI), while correlation analysis is used to determine the relationship between the observed variables. Table 7 shows the correlation analysis results.

Table 7. Correlation analysis

\begin{tabular}{ccccccccc}
\hline & Total P & Available K & C-organic & Soil Depth & $\mathrm{pH}$ & Sand & Silt & Clay \\
\hline Total P & 1.000 & & & & & & & \\
Available K & 0.206 & 1.000 & & & & & & \\
C-organic & 0.222 & 0.262 & 1.000 & & & & & \\
Soil Depth & -0.328 & -0.243 & -0.389 & 1.000 & & & & \\
pH & -0.062 & 0.036 & 0.018 & 0.113 & 1.000 & & & \\
Sand & 0.096 & -0.138 & $-0.543^{*}$ & 0.264 & -0.155 & 1.000 & & \\
Silt & 0.118 & 0.048 & 0.125 & -0.073 & 0.312 & -0.213 & 1.000 & \\
Clay & -0.157 & -0.017 & 0.443 & -0.100 & 0.374 & $-0.836^{*}$ & 0.245 & 1.000 \\
\hline
\end{tabular}

Note: * significant

Table 7 shows the correlation analysis results for each soil variable. Sand and clay fractions have the highest correlation compared to other variables, with a value of -0.836 . A negative value indicates that the relationship between the two is reversing. When the sand fraction value is high, the clay fraction value tends to be low and vice versa. Furthermore, the lowest correlation result was found between $\mathrm{C}$-organic and $\mathrm{pH}$ variables with a value of 0.018, which is in the shallow category. Fetene \& Amera (2018) stated that c-organic has more effect on soil porosity and volume weight. The next procedure was extraction via principal component analysis (PCA). The extraction results were in the form of minimum data sets used in scoring and determining the soil quality index (SQI).

Table 8 shows the principal component extraction results. The P-total as well as silt,and clay fraction variables were used in the SQI assessment. The significance level of the three variables was determined by the eigen value (Mukherjee \& Lal, 2014). To be used as an MDS indicator, this value needs to be $>1$ (Romadhona \& Arifandi, 2020). The eigen values for the principal components (PC) 1, 2, and 3 were all greater than one, hence, the three are applicable as MDS indicators.

The eigenvectors $>90 \%$ of the maximum value in each PC were used as an MDS indicator (Supriyadi et al., 2018). Table 8 shows the three indicators of MDS, i.e., clay and silt fraction, as well as total P. The MDS factor weight was obtained by dividing the variance $(\%)$ by the cumulative $(\%)$ on PC3 with values of $0.477,0.309$, and 0.214 respectively. This weight value was used in the calculation of the soil quality index (SQI). 
Putri Tunjung Sari et al. / Geosfera Indonesia 6 (2), 2021, 173-188

Table 8. PCA results

\begin{tabular}{|c|c|c|c|}
\hline PCs & PC1 & PC2 & PC3 \\
\hline Eigenvalue & 2.58 & 1.68 & 1.16 \\
\hline$\%$ of Variance & 32.28 & 20.96 & 14.45 \\
\hline Cumulative $\%$ & 32.28 & 53.24 & 67.68 \\
\hline \multicolumn{4}{|l|}{ Eigenvectors } \\
\hline P_total & 0.117 & $0.696^{*}$ & 0.406 \\
\hline K_available & 0.294 & 0.493 & 0.178 \\
\hline C_organic & 0.743 & 0.312 & -0.200 \\
\hline Soil depth & -0.445 & -0.623 & 0.080 \\
\hline $\mathrm{pH}$ & 0.341 & -0.478 & 0.585 \\
\hline Sand & -0.874 & 0.184 & 0.295 \\
\hline Silt & 0.410 & -0.150 & $0.677 *$ \\
\hline Clay & $0.827 *$ & -0.423 & -0.163 \\
\hline
\end{tabular}

Note: $*$ MDS variable

\subsection{Assessment of Soil Quality Index (SQI)}

Soil quality index assessment only used the PCA result variable. Three main factors were used to determine the soil quality index, i.e., the clay and silt fraction, as well as P-total. The results were categorized into three classes, i.e., very low, low, and medium (Figure 5). Furthermore, the map analysis results showed that $41.14 \%$ was in the very low category, $52.23 \%$ was in a low class, and $6.63 \%$ was in the medium category.

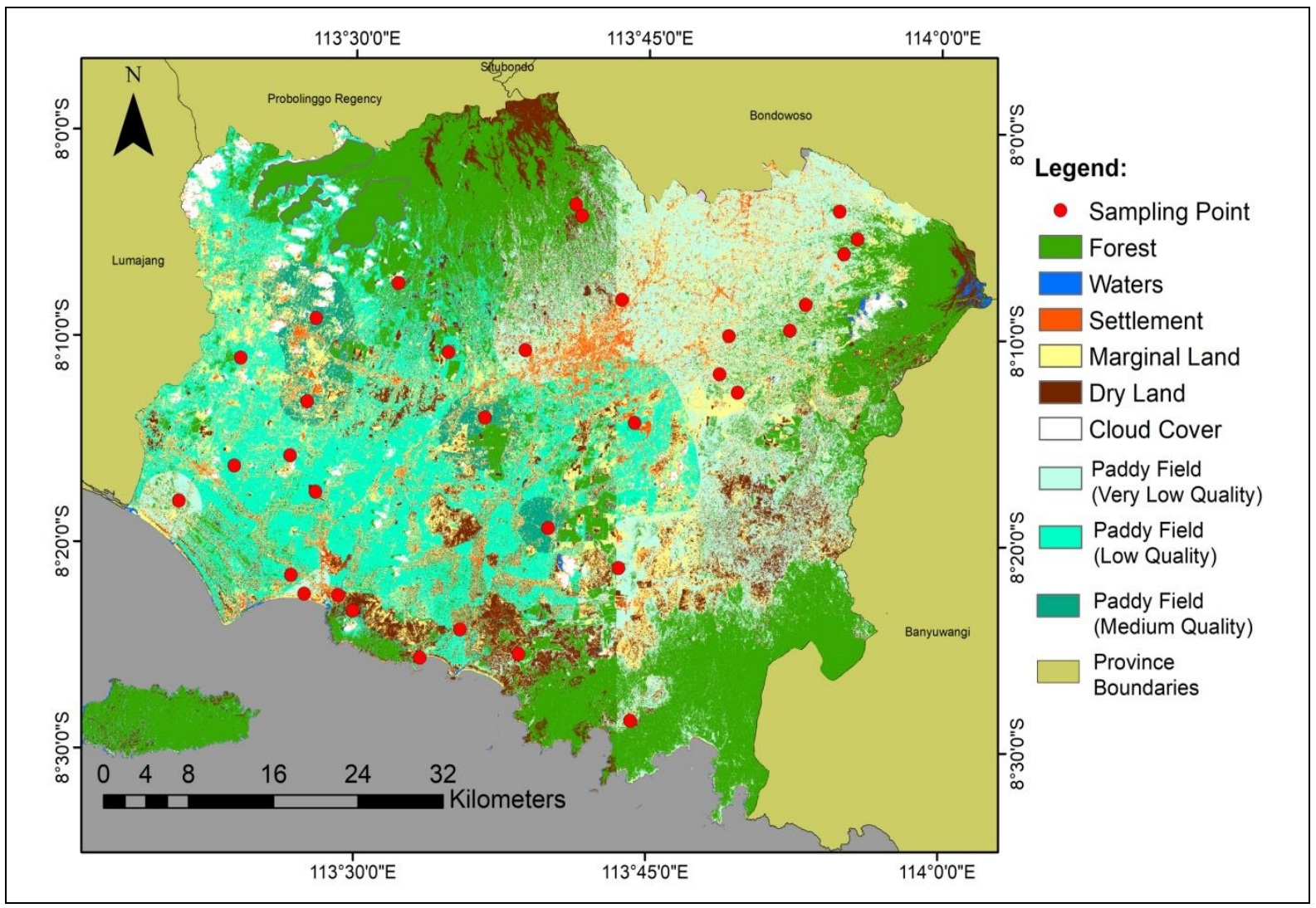

Figure 5. Soil Quality Index (SQI) paddy fields in Jember Regency 
The low quality of paddy fields is due to intensive soil management and chemical inputs. In addition, majority of farmers use only chemical fertilizers without any organic supplement. Meanwhile, organic fertilizers are released slowly, and the results are not visible (Maas et al., 2017). The application of chemical fertilizers has a direct effect on plants (Asvini \& Jithesh, 2018), therefore, most farmers do not use organic fertilizers.

This condition shows that there is a need to improve the quality of the paddy soil to support sustainability. Soil quality improvement needs to focus on improving soil fertility without damaging the environment. Meanwhile, soil fertility is a determining factor in plant growth and development (Karamanoli et al., 2017). Organic fertilizers are applied to increase nutrient availability and soil physical properties (Kidinda et al., 2015).

\section{Conclusion}

Based on the results, three variables were found to strongly influence soil quality assessment namely total $\mathrm{P}$, as well as clay and silt fraction. Approximately $93.37 \%$ of the paddy field area was classed as very low-low quality due to the intensive use of chemical fertilizers without organic supplements. The addition of ameliorants such as organic fertilizer is needed to improve the soil's physical, chemical, and biological properties. This application is to be focused on areas with very low - low soil quality to increase the quality to medium.

\section{Conflict of Interest}

The authors declare no conflict of interest.

\section{References}

Abdel Rahman, M. A. E., Zakarya, Y. M., Metwaly, M. M., \& Koubouris, G. (2021). Decisphering soil spatial variability through geostatistics and interpolation techniques. Sustainability (Switzerland), 13(1), 1-13. https://doi.org/10.3390/su13010194.

Arunrat, N., Kongsurakan, P., Sereenonchai, S., \& Hatano, R. (2020). Soil organic carbon in sandy paddy fields of Northeast Thailand: A review. Agronomy, 10(8), 1-25. https://doi.org/10.3390/agronomy10081061.

Asvini, B., \& Jithesh. (2018). Impact of Using Artificial Fertilizer in Soil. International Journal of Pure and Applied Mathematics, 119(17), 47-55.

Bahnemiri, A. K., Abkenar, K. T., Kooch, Y., \& Salehi, A. (2019). Valuation of soil and litter quality indices using analysis hierarchical process (AHP) in Hyrcanian beech forest stands, Northern Iran (Case study: Korkoroud forests in Noshahr). Journal of Forest Science, 65(10), 397-407. https://doi.org/10.17221/54/2019-JFS. 
Putri Tunjung Sari et al. / Geosfera Indonesia 6 (2), 2021, 173-188

Balai Penelitian Tanah (2015). Soil Type Map. Retrieved from https://balittanah.litbang.pertanian.go.id/ind/.

Banerjee, H., Ray, K., Dutta, S. K., Majumdar, K., Satyanarayana, T., \& Timsina, J. (2018). Optimizing Potassium Application for Hybrid Rice (Oryza sativa L.) in Coastal Saline Soils of West Bengal, India. Agronomy, 8(12), 1-14. https://doi.org/10.3390/agronomy8120292.

BIG (1999). Seamless Digital Elevation Model (DEM) dan Batimetri Nasional. Retrieved from $\mathrm{h}$ http://tides.big.go.id/DEMNAS/.

Bofana, J. do R., \& Costa, A. C. C. (2017). Comparison of spatial interpolators for variability analysis of soil chemical properties in Cuamba (Mozambique). African Journal of Agricultural Research, 12(25), 2153-2162. https://doi.org/10.5897/ajar2016.12415.

Eviati \& Sulaeman. (2009). Petunjuk Teknis Analisis Kimia Tanah, Tanaman, Air dan Pupuk. Jakarta : Balai Penelitian Tanah.

Fetene, E. M., \& Amera, M. Y. (2018). The effects of land-use types and soil depth on soil properties of Agedit watershed, Northwest Ethiopia. Ethiopian Journal of Science and Technology, 11(1), 39. https://doi.org/10.4314/ejst.v11i1.4.

Hanafiah, K. . (2018). Basic of Soil Science. Depok : Raja Grafindo Persada.

Hore, R., Chakraborty, S., Bari, M. F., Shuvon, A. M., \& Ansary, M. A. (2020). Soil Zonation and The Shaking Table Test of The Embankment on Clayey Soil. Geosfera Indonesia, 5(2), 196-209. https://doi.org/10.19184/geosi.v5i2.17873.

Hung, D. T., Hughes, H. J., Keck, M., \& Sauer, D. (2019). Rice-residue management practices of smallholder farms in Vietnam and their effects on nutrient fluxes in the soilplant system. Sustainability (Switzerland), 11(1641), 1-15. https://doi.org/10.3390/su11061641.

Japan International Cooperation Agency (JICA) (2014). Soil Analysis Manual. Bandung : NTC International Co., Ltd.

Johannes, H. P., Priadi, C. R., \& Herdiansyah, H. (2019). Organic rice farming: An alternative to sustainable agriculture. IOP Conference Series: Materials Science and Engineering, 546(2). https://doi.org/10.1088/1757-899X/546/2/022008.

Karamanoli, K., Papaioannou, A., \& Sofogianni, S. (2017). Soil fertility and productivity estimation of Pinus pinaster Aiton reforestations in Central and Northeast Chalcidice in Northern Greece. Journal of Forest Science, 63(10), 470-475. https://doi.org/10.17221/68/2017-JFS.

Kidinda, L. K., Bandi, B. T. K.-, Mukalay, J. B., Kabemba, M. K., Ntata, C. N., Ntale, T. M., Tamina, D. T., \& Kimuni, L. N. (2015). Impact of Chicken Manure Integration with Mineral Fertilizer on Soil Nutriments Balance and Maize (Zea mays) Yield: A Case Study on Degraded Soil of Lubumbashi (DR Congo). American Journal of Plant Nutrition and Fertilization Technology, 5(3), 71-78. https://doi.org/10.3923/ajpnft.2015.71.78. 
Li, D., Nanseki, T., Chomei, Y., \& Fukuhara, Y. (2018). Impact of soil chemical properties on rice yield in 116 paddy fields sampled from a large-scale farm in Kinki Region, Japan. IOP Conference Series: Earth and Environmental Science, 185(1). https://doi.org/10.1088/1755-1315/185/1/012026.

Lin, H. C., \& Fukushima, Y. (2016). Rice cultivation methods and their sustainability aspects: Organic and conventional rice production in industrialized tropical monsoon Asia with a dual cropping system. Sustainability (Switzerland), 8(529), 1-23. https://doi.org/10.3390/su8060529.

Maas, E. D. V. L., Lal, R., Coleman, K., Montenegro, A., \& Dick, W. A. (2017). Modeling soil organic carbon in corn (Zea mays L.)-based systems in Ohio under climate change. Journal of Soil and Water Conservation, 72(3), 191-204. https://doi.org/10.2489/jswc.72.3.191.

Mohawesh, Y., Taimeh, A., \& Ziadat, F. (2015). Effects of land-use changes and soil conservation intervention on soil properties as indicators for land degradation under a Mediterranean climate. Solid Earth, 6(3), 857-868. https://doi.org/10.5194/se-6-8572015.

Mukherjee, A., \& Lal, R. (2014). Comparison of soil quality index using three methods. PLoS ONE, 9(8), 1-16. https://doi.org/10.1371/journal.pone.0105981.

Nusantara, R. W., Aspan, A., Alhaddad, A. M., Suryadi, U. E., Makhrawie, Fitria, I., Fakhrudin, J., \& Rezekikasari. (2018). Peat soil quality index and its determinants as influenced by land use changes in kubu Raya district, West Kalimantan, Indonesia. Biodiversitas, 19(2), 540-545. https://doi.org/10.13057/biodiv/d190229.

Panday, D., Ojha, R. B., Chalise, D., Das, S., Twanabasu, B., \& Tejada Moral, M. (2019). Spatial variability of soil properties under different land use in the Dang district of Nepal. Cogent Food \& Agriculture, 5(1), 1-19. https://doi.org/10.1080/23311932.2019.1600460.

Pierzynski, G. M., Sims, J. T., \& Vance, G. F. (2005). Soil and Environmental Quality. Florida : CRC Press Taylor and Francis Group.

Reddy, R. S., Babu, G. A., \& Reddy, A. R. M. (2020). Geospatial Approach for the Analysis of Forest Cover Change Detection using Machine Learning. Geosfera Indonesia, 5(3), 335-351. https://doi.org/10.19184/geosi.v5i3.20157.

Ren, X., Chen, F., Ma, T., \& Hu, Y. (2020). Soil quality characteristics as affected by continuous rice cultivation and changes in cropping systems in South China. Agriculture (Switzerland), 10(10), 1-11. https://doi.org/10.3390/agriculture10100443.

Romadhona, S., \& Arifandi, J. A. (2020). Indeks Kualitas Tanah Dan Pemanfaatan Lahan Sub Daerah Aliran Sungai Suco Kabupaten Jember. Geography: Jurnal Kajian, Penelitian Dan Pengembangan Pendidikan, 8(1), 37-45.

Roy, R., Chan, N. W., \& Xenarios, S. (2015). Sustainability of rice production systems: an empirical evaluation to improve policy. Environment, Development, and Sustainability, 18(1), 257-278. https://doi.org/10.1007/s10668-015-9638-x. 
Putri Tunjung Sari et al. / Geosfera Indonesia 6 (2), 2021, 173-188

Seifu, W., \& Elias, E. (2018). Soil Quality Attributes and Their Role in Sustainable Agriculture: A Review. International Journal of Plant \& Soil Science, 26(3), 1-26. https://doi.org/10.9734/ijpss/2018/41589.

Supriyadi, Mustikaningrum, I. A., Herawati, A., Purwanto, P., \& Sumani, S. (2018). Soil quality assessment in organic and non-organic paddy fields in Susukan, Indonesia. Bulgarian Journal of Agricultural Science, 24(5), 777-784.

Supriyadi, S., Sih Dewi, W., Nugrahani, D., Rahmah, A. A., Haryuni, H., \& Sumani, S. (2019). The Assessment of Soil Quality Index for Paddy Fields with Indicator Biology in Jatipurno Districts, Wonogiri. Modern Applied Science, 14(1), 20-33. https://doi.org/10.5539/mas.v14n1p20.

Terano, R., Mohamed, Z., Shamsudin, M. N., \& Latif, I. A. (2015). Farmers sustainability index: The case of paddy farmers in state of Kelantan, Malaysia. Journal of the International Society for Southeast Asian Agricultural Sciences, 21(1), 55-67.

USDA - Soil Survey Staff. (2014). Keys to soil taxonomy. Washington DC : USDA.

USGS (2019). Sentinel-2 Imagery. Retrived from https://www.usgs.gov/centers/eros/science/usgs-eros-archive-sentinel-2.

Van Grinsven, H. J. M., Erisman, J. W., De Vries, W., \& Westhoek, H. (2015). Potential of extensification of European agriculture for a more sustainable food system, focusing on nitrogen. Environmental Research Letters, 10(2). https://doi.org/10.1088/17489326/10/2/025002.

Xie, H., Huang, Y., Chen, Q., Zhang, Y., \& Wu, Q. (2019). Prospects for agricultural sustainable intensification: A review of research. Land, 8(11), 1-27. https://doi.org/10.3390/land8110157.

Yao, H., Chen, X., Yang, J., Li, J., Hong, J., Hu, Y., \& Mao, X. (2020). Effects and mechanisms of phosphate activation in paddy soil by phosphorus activators. Sustainability (Switzerland), 12(9), 1-15. https://doi.org/10.3390/su12093917. 